\title{
UMP-CMP Kinase
}

National Cancer Institute

\section{Source}

National Cancer Institute. UMP-CMP Kinase. NCI Thesaurus. Code C150217.

UMP-CMP kinase (196 aa, $22 \mathrm{kDa}$ ) is encoded by the human CMPK1 gene. This protein plays a role in catalyzing the synthesis of cytidine and uridine diphosphate. 